\title{
Change Unplanned into Planned Online Learning: An Effort to Follow Health Protocols at an Information Technology College During the Covid-19 Pandemic Period
}

\author{
*M.J. Dewiyani Sunarto ${ }^{1}$ \\ 1Universitas Dinamika, Surabaya 60298, Indonesia
}

\begin{tabular}{l} 
Article Info \\
\hline Article history: \\
Received March 30, 2021 \\
Revised April 27, 2021 \\
Accepted April 28, 2021 \\
Available Online April 30, 2021 \\
\hline
\end{tabular}

Keywords:

Covid-19

Health Protocol

Information Technology

Online Learning

\begin{abstract}
The Covid-19 pandemic not only has negative impacts, but also positive impacts, one of those is the development of online learning. Online learning, of course, does not mean simply moving face-to-face encounters to virtual ones, as happened during the first semester of the Covid-19 pandemic. The problem to be solved in this study is how to change sudden/unplanned online learning in the first semester of the Covid-19 pandemic into planned online learning in the second semester based on theoretical studies, and to define if there are changes in student responses in the two consecutive semesters. The results obtained are a theoretical study for the formation of planned online learning, as well as an increase in the results of student responses via questionnaires which indicate progress in efforts to prepare unplanned online learning into planned online learning.
\end{abstract}

\section{INTRODUCTION}

The Covid-19 pandemic, which has lasted for 2 consecutive semesters, has been able to change the entire structure of human life, both in everyday life and specifically in the world of education. Big changes in the world of education have occurred simultaneously, especially in the models and learning media used. Because physical encounters are no longer possible, while the teaching and learning process is impossible to stop, people in the world of education are looking for ways to continue the teaching and learning process (Simamora, 2020), (Famularsih, 2020), (Simamora, D de Fretes, \& Purba, 2020). Online learning is the only alternative so that teaching and learning process can keep going. All levels of education are competing to use this alternative, starting from the simplest way, for example by empowering WhatsApp features, namely chat, video, and file attachment. Although this simple method often does not achieve maximum results but it is commonly used, especially at the basic education level. In addition to this simple method, some have used more sophisticated media, namely by using web conferencing such as zoom, gmeet, or other media, even combined those with other applications such as Open Broadcaster Software (OBS) to make it look more attractive and easily understood by students. In addition to the variety of applications or tools used, the learning models used are also varied, such as using flipped learning (Tang, et al., 2020), blended learning (Fadillah, Nopitasari, \& P. Pradja, 2020).

From the variety of learning applications and learning models used during the pandemic period, the college where this study was conducted is trying to find an online learning model that does not only move from face-to-face to online learning with web conferencing or other applications, but looks for a combination that is right between learning settings and learning strategies to produce learning outcomes as expected (Chaeruman, Wibawa, \& Syahrial, 2020). Thus, the question proposed in this study is, what efforts are being made by the college, where this study taken place, which can change online learning that was originally carried out 
Change Unplanned Into Planned Online Learning: An Effort To Follow Health Protocols At An Information Technology College During The Covid-19 Pandemic Period

https://doi.org/10.46627/silet.v2i1.62

unplanned into planned online learning, in accordance with the theoretical study of the learning model and learning applications used, as well as in accordance with the wishes of students obtained through questionnaires?

That question absolutely needs an answer (s), considering that the first semester of the pandemic period which occurred very suddenly for online learning at the college where this research was carried out, caused learning preparation to be very minimal. The decision to go online was even a week before lectures began. Some lecturers were not familiar with applications such as google meet, zoom or others, so many lecturers had to focus on trying to learn them, while learning had to take place. The college had not had time to think of the right strategies for online learning. Lecturers try their own way to continue to be able to carry out learning as well as possible, even though the results were not optimal, and it was just like moving class meetings physically to virtual ones (Bestiantono, Agustina, \& T-H Cheng, 2020), (Almarzooq, Lopes, \& Kochar, 2020). That unplanned learning process took place for 1 semester. At the end of the semester, questionnaires were distributed to students to find out their responses to the online learning that was taking place. Based on the awareness that there is not yet an appropriate model for online learning and students' questionnaire responses, it is necessary to think about learning strategies to deal with online learning in the second semester of the pandemic.

In order to find answers to the problems proposed, the definition of online learning and how to use it at the college level must be determined first, and then how online learning is used during the pandemic.

There are quite a number of definitions regarding online learning including (Bakia, Shear, Toyama, \& Lasseter, 2012), (Nguyen, 2015), (Dhull \& MS. Sakshi, 2017), (El-Seoud, Taj-Eddin, Seddiek, M. El-Khouly, \& Nosseir, 2014), (Arkorful \& Abaidoo, 2014) who state that the learning carried out must be in the internet environment for the provision of teaching materials, and be carried out without the limitations of space, time, and without face to face meeting between educators and students. In this study, the definition of online learning, by adjusting the situation during the pandemic, is learning that is carried out by eliminating face-to-face meeting, and relying on the internet as a learning tool, the existence of certain learning models, and using learning applications such as moodle as an e-learning media adapted to the learning model.

The first element of online learning definition during the pandemic is no face-to-face meeting. This is the most important element in breaking the covid chain, according to circular letter from the Ministry of Education and Culture of the Republic of Indonesia since March 2020, through Press Release No. 064/Sipres/ A61lll/2020 concerning Prioritizing Covid-19 Prevention, March 20, 2020. All physical encounters were eliminated, as well as all learning process in various countries (Adedoyin \& Soykan, 2020), (Tang, et al., 2020), (Al-Maroof, A. Salloum, Hassanien, \& Shaalan, 2020), (Lemay, Doleck, \& Bazelais, 2021). All were looking for ways to minimize physical meetings as possible, because at that time, the world forbade physical interaction to break the pandemic chain. The situation is not completely negative, but it also has positive impacts on the world of education, namely online learning that has been initiated for years and not widely implemented, suddenly becoming a learning model that is used by everyone.

The second element is relying on the power of the Internet as the only medium that can facilitate online learning to keep going. All media used for learning, starting from the simplest to the most sophisticated ones, like Whatsapp, Google Meet, Youtube, OBS use internet as life to stay connected. The nature of the Internet which allows everyone to always be connected to anyone, anywhere and anytime is in great demand for both synchronous and asynchronous learning (Tuaycharoen, 2021). In times of inability to meet in person, encounter through network is the most possible one (Arkorful \& Abaidoo, 2014).

No less important is the third element, namely the use of learning applications to accommodate existing teaching tools, and manage them well, including being used to distribute learning materials, collaboration between educators and students, storing test results and other activities. There are various kinds of learning applications that can be used freely (open source), 
such as Moodle, Blackboard CourseSite, Google Classroom, Edmodo, Schoology, etc. Of the many types of learning applications, the college uses Moodle-based learning application. Indeed, Moodle is widely used both at the college and high school levels, and has received positive responses from its users (Yildiz, Tezer, \& Uzunboylu, 2018).

The fourth element is a conceptual framework to describe a systematic procedure for organizing learning experiences in order to achieve learning goals or what is known as learning model. According to (Trianto, 2014), learning model is a plan or a pattern that is used as a guide in planning classroom learning. The learning model refers to the learning approach that will be used, including the objectives of teaching, the stages in learning activities, the learning environment and classroom management. Learning model is a pattern of interaction between students and educators in the classroom related to approaches, strategies, methods, learning techniques applied in the implementation of teaching and learning activities.

According to (Eggen \& Kauchak, 2011), a learning model is a learning perspective strategy designed to achieve certain learning goals. A learning model is a perspective in such a way that educators are responsible during the planning, implementation, and assessment stages of learning.

According to (Joyce, 2014), learning model is a plan or a pattern that is used as a guide in planning classroom learning or tutorial learning and to determine learning tools including books, films, computers, curriculums, and others. Each model directs us in designing learning to help students so that learning objectives are achieved.

(Joyce, 2014) also revealed that there are five important elements that describe a learning model, namely (1) syntax, which is a learning sequence, and is commonly referred to as phase, (2) the social system, namely the roles of students and educators and the norms required, (3) the principle of reaction, which gives educators an overview of how to view and respond to what students do, (4) the support system, namely the conditions or circumstances needed for the implementation of a model, such as class settings, instructional systems, learning tools, learning facilities, and learning media, and (5) instructional and accompaniment impacts. Instructional impact is learning outcomes that are achieved directly by directing students to the expected goals, while the accompaniment impact is other learning outcomes produced by a teaching and learning process, as a result of creating a learning atmosphere experienced directly by students without direct direction from educator.

According to (Arends, 2014) the term of learning model has two explanations, namely: (1) the model implies something broader than strategy, method or structure, and includes a number of approaches for teaching, and (2) a learning model serves as an important means of communication in class or practice of learners. Furthermore, it is explained that a learning model refers to the learning approach used, including learning objectives, stages in learning activities, learning environment and class management. Furthermore, Arends provides four special characteristics of a learning model that a strategy does not have, namely (1) rational logical theory compiled by its creator or developer, (2) a basis for thinking about what and how learners learn (learning objectives that will be achieved), (3) teaching behavior required for the model to be implemented successfully, and (4) learning environment necessary for the learning objectives to be achieved.

Based on several references about learning models, in this model book, the learning model is defined as a conceptual framework that describes a systematic procedure for organizing learning experiences to achieve learning goals. The function of a learning model here is as a guide for teaching designers and educators in carrying out learning. The choice of this model is strongly influenced by the nature and material to be taught, and is also influenced by objectives to be achieved in the teaching and ability level of students. In addition, each learning model always has stages (syntax) by students with the guidance of educators. One syntax and another also has differences. These differences take place between the opening and closing which must be understood by educators so that learning models can be implemented successfully. The direction 
of the learning model this time is based on online learning due to the Covid-19 pandemic. (Sunarto, 2021) through several references that have been done, found out that flipped learning model is the most appropriate learning model to use when learning online. In general, the syntax of flipped learning (Bergmann \& Sams, 2012) are (1) activities at the first day in the flipped learning model, (2) informing the flipped learning model to students, (3) explaining to students how to access the tools used, (4) Asking students to prepare questions, (5) Guiding students to collaborate, (6) creating a scoring system, (7) Students developing knowledge through data literacy. In this study, a learning model will be developed based on flipped learning, but there are adjustments made to the conditions or the environment and existing facilities.

\section{RESEARCH METHODS}

\section{Sample and Population}

The change of unplanned online learning into planned online learning was tested simultaneously on active students where this study was conducted, with a total of 1,320 respondents. This number does not mean the number of total students, but the number of participants in each class of the existing courses.

\section{Instrument and Procedure}

The procedure of this study can be described as in Figure 1.

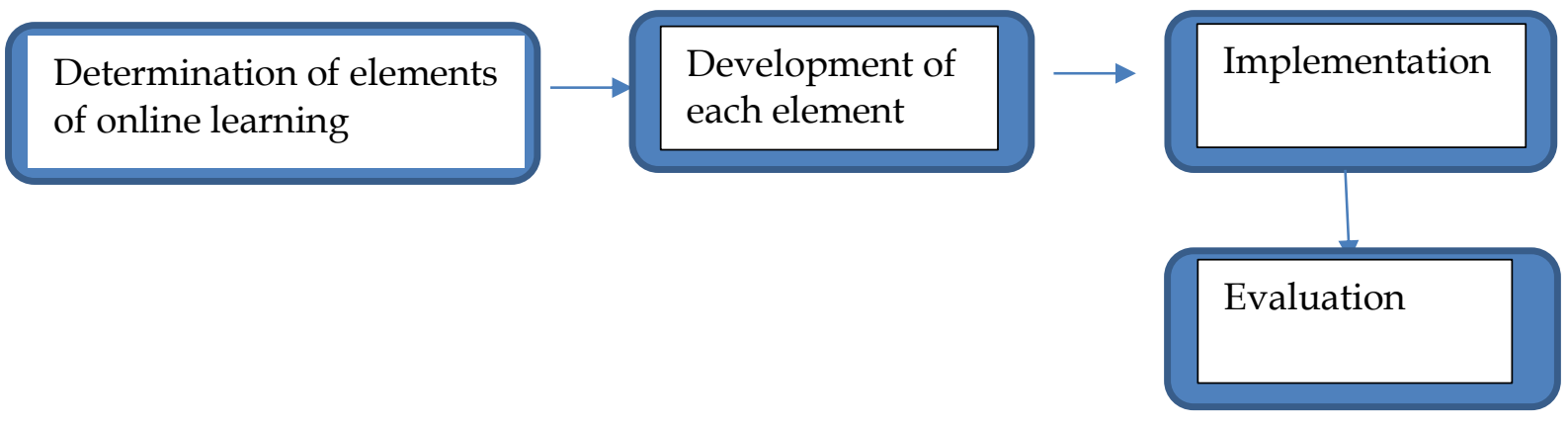

Figure 1. Research Procedure

This study used questionnaire response of students as research instrument, and was processed with descriptive statistics. The data analysis technique used is quantitative, with inferential analysis.

\section{RESULT AND DISCUSSION}

The description of each stage in the procedure can be described as follows:

\section{Stage 1: Determine the elements of online learning}

Online learning, which is definitely different from face-to-face learning, has several main elements that must be fulfilled in its implementation. From several references it was found that the main elements of online learning are the absence of face-to-face meeting, relying on the internet, using a learning model and learning applications that support the learning model (Arkorful \& Abaidoo, 2014), (Nassren, Abdullah Alawi, \& Shagufta, 2014), (Bakia, Shear, Toyama, \& Lasseter, 2012), (Sun \& Chen, 2016), (Al-Fraihat, Joy, \& Sinclair, 2017), (Parsazadeh, Mohd Zainuddin, Ali, \& Hematian , 2013), (Alqahtani \& A. Rajkhan, 2020), (Alhomod \& Shafi, 2013).

\section{Stage 2: Development of each element}

Based on the analysis in stage 1, there are 3 main elements that must be developed in order to become planned online learning, namely relying on the internet, using learning applications, and the existence of certain learning models. 
The first element is the existence of internet. It is no longer a problem for the college where this research was conducted, because internet is already capable, both in terms of speed and capability. The first element needs no further development. This college is indeed ready in terms of internet and information technology support (Sunarto, 2021)

The second element is the existence of a learning model. The learning model that will be used in a planned way is based on flipped learning, because this model is considered to be the most adequate for online learning (Sunarto, 2021). The phases that will be used are introduction, exploration, study, presentation and assessment.

In general, the description of each phase is:

Table 1. Phases of Flipped Learning-Based Learning Model

\begin{tabular}{llll}
\hline Phase & \multicolumn{1}{c}{ Purpose } & \multicolumn{2}{c}{ Teaching Learning Activities } \\
\cline { 3 - 4 } & & \multicolumn{1}{c}{ Educator } & \multicolumn{1}{c}{ Student } \\
\hline Introduction & To attract students' interest, make & - Prepare materials. & - Download materials \\
& them focus, and motivate them to & - Upload materials on & from the LMS. \\
& take active role in learning. & LMS (text, videos, articles & - Learn materials. \\
& & and others).
\end{tabular}

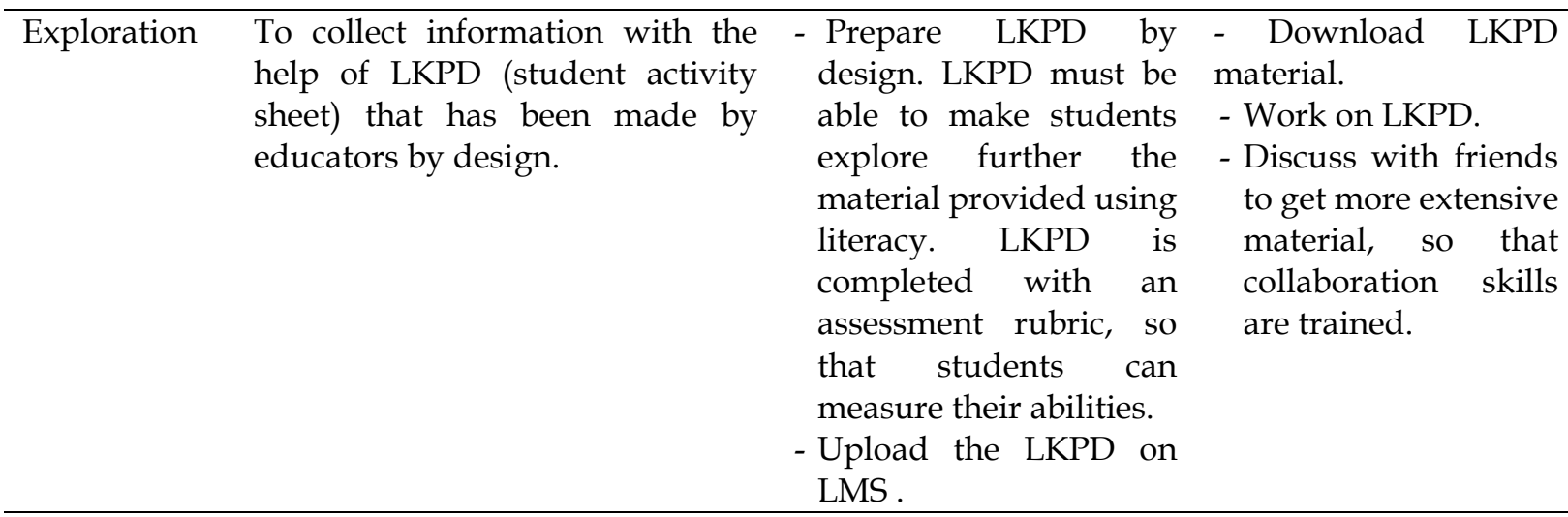

Study To guide students in making - Discuss with students, - Deliver the results of
analysis, conclusions and to guide them in discussions with discussion of the exploration producing conclusions, friends to educators, results. in preparation for entering the next phase. Discussions can be done in groups, and take place outside of routine hours. in order to get direction, as a preparation for entering the next syntax.

\begin{tabular}{|c|c|c|c|}
\hline Presentation & $\begin{array}{l}\text { To help students in making } \\
\text { conclusions and discussion from } \\
\text { their investigation results of } \\
\text { various representations, and } \\
\text { assisting and guiding students in } \\
\text { planning, preparing, and }\end{array}$ & $\begin{array}{l}\text { Educators facilitate the } \\
\text { effective discussion and } \\
\text { help make conclusions. }\end{array}$ & $\begin{array}{l}\text { Students deliver the } \\
\text { results of the } \\
\text { discussion, by } \\
\text { presenting them so } \\
\text { that communication } \\
\text { skills are trained. }\end{array}$ \\
\hline
\end{tabular}

\begin{tabular}{lllrl}
\hline Assessment & $\begin{array}{l}\text { To evaluate the problem-solving } \\
\text { process of scientific activities / } \\
\text { investigations. }\end{array}$ & $\begin{array}{l}\text { Educators conduct } \\
\text { evaluations so that } \\
\text { students can develop } \\
\text { their knowledge, to }\end{array}$ & $\begin{array}{l}\text { Students begin to } \\
\text { think about scientific } \\
\text { produce scientific work, that must be } \\
\text { produced at the end } \\
\text { in ofder to sharpen their lecture, using } \\
\text { creativity. }\end{array}$ & $\begin{array}{l}\text { the discussion } \\
\text { results and direction } \\
\text { of educator. }\end{array}$ \\
\hline
\end{tabular}


The third element is the existence of Learning Application as an LMS (Learning Management System). This element is important to be held, because it is connection for educators to send material to students, so that it does not become remote learning. In the college where this study was carried out, the learning application used an application called Brilian, a learning application specifically made and started to be used since the second semester of the Covid 19 pandemic period. Before the pandemic, Brillian was already used, but on a different basis.

Some of the things that become the development of Brilliant application are:

a. Using the Moodle base as the best open source LMS provider in 2020 (Pappas, 2020).

b. Supports the syntax of the learning model (introduction, exploration, study, presentation, assessment).

In addition to Brillian development, preparation of human resources is also needed, so that several activities are made, they are:

a. Conduct training for all educators to make teaching materials so that Phase 1 , namely the introduction, can be well received by students.

b. Providing Brillian training to all educators.

c. Make a Chancellor's Decree stated that all educators must use Brillian, along with their rights and obligations.

The menu at Brillian that supports each phase is:

Table 2. Menu on Brillian as Support for every Phase of the Learning Model

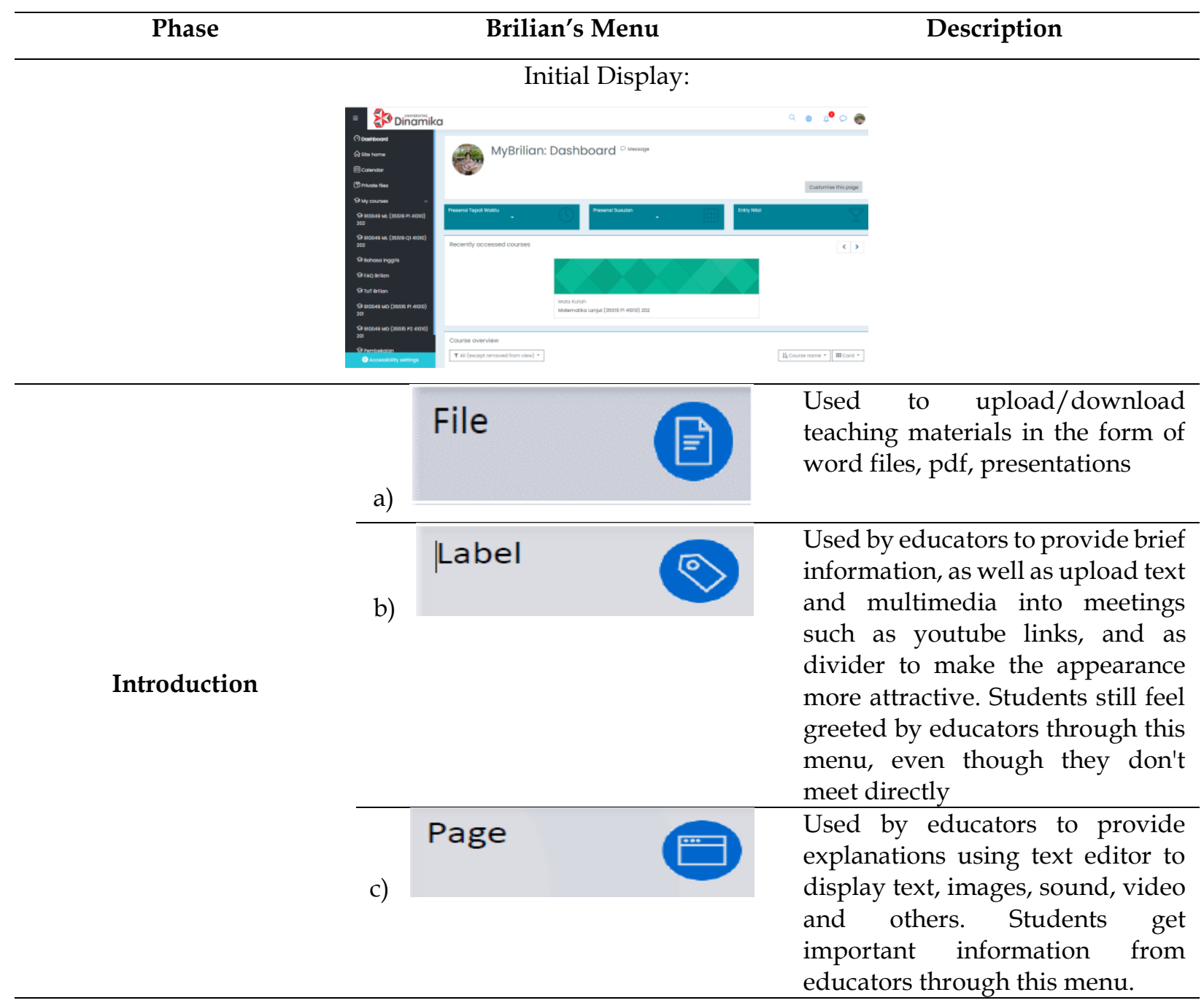




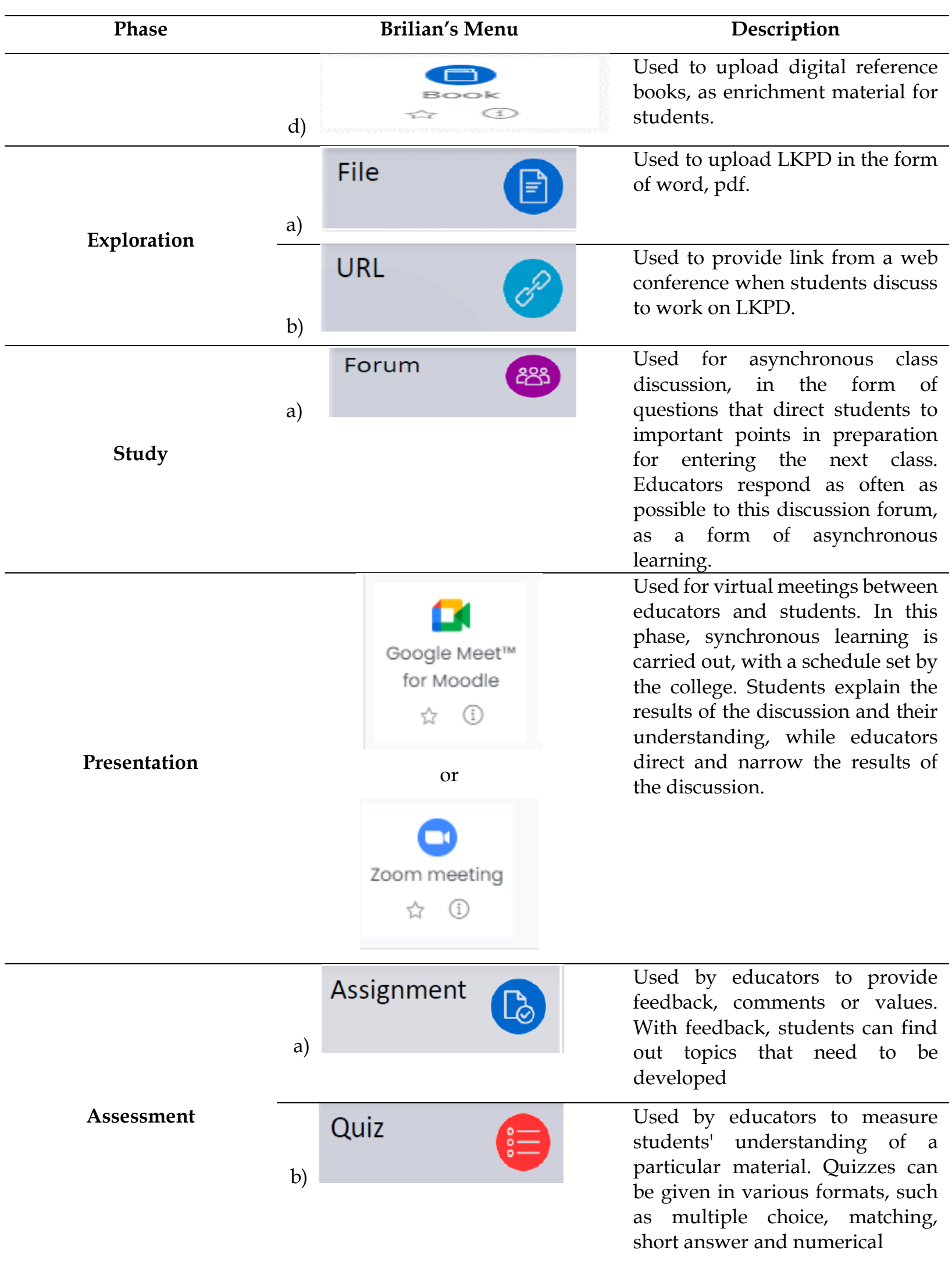

(Sutomo, et al., 2020), (Moodle, 2020).

\section{Stage 3. Implementation}


After the development of each element had been completed, entering the second semester of the Covid-19 pandemic period, every educator, based on the Chancellor's Decree, has obligation to make changes to planned online learning. A total of 377 classes, from 9 study programs and 2 faculties were involved in the implementation of this planned online learning.

\section{Stage 4. Evaluation}

After a full semester passed by lecturers with planned online learning, students were simultaneously asked to fill out an online student response questionnaire. The results of the questionnaire responses from the planned online learning were compared with the results of the questionnaire responses during the unplanned online learning period.

The questions given were adjusted to changes to online learning so that the items in questionnaires taken are shown in table 3.

Table 3. Questions on student response questionnaires, objectives and comparison of results.

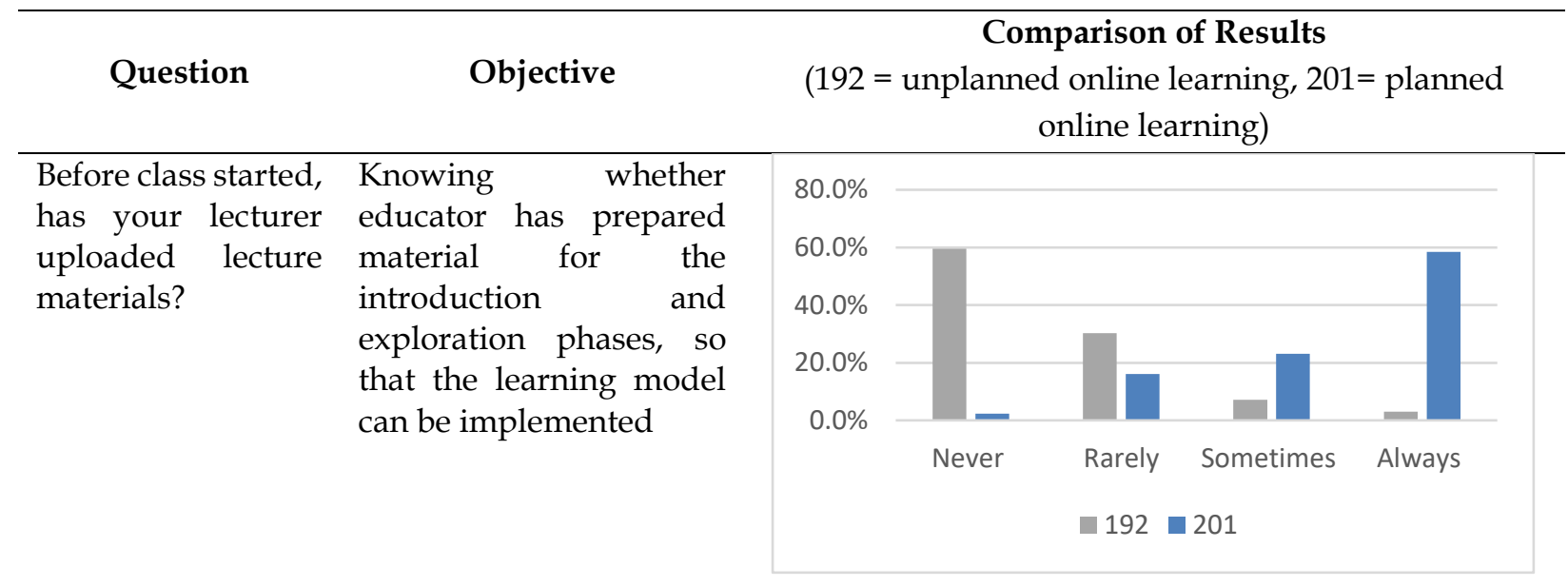

\begin{tabular}{ll}
\hline $\begin{array}{l}\text { Does your lecturer } \\
\text { require you to read }\end{array}$ & $\begin{array}{l}\text { Knowing whether } \\
\text { educator has accustomed }\end{array}$ \\
the material & students to reading and \\
presented before & studying the material \\
class? & first, in accordance with \\
& the concept of flipped \\
& learning.
\end{tabular}

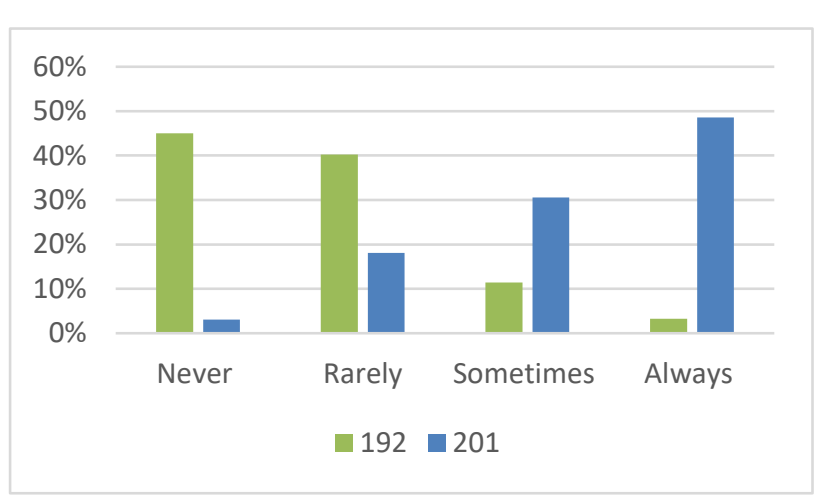

Each time online Knowing how far class will take students have been place, do you study accustomed to studying the material that material independently your lecturer had before lecture, in uploaded first?. accordance with the concept of flipped learning.

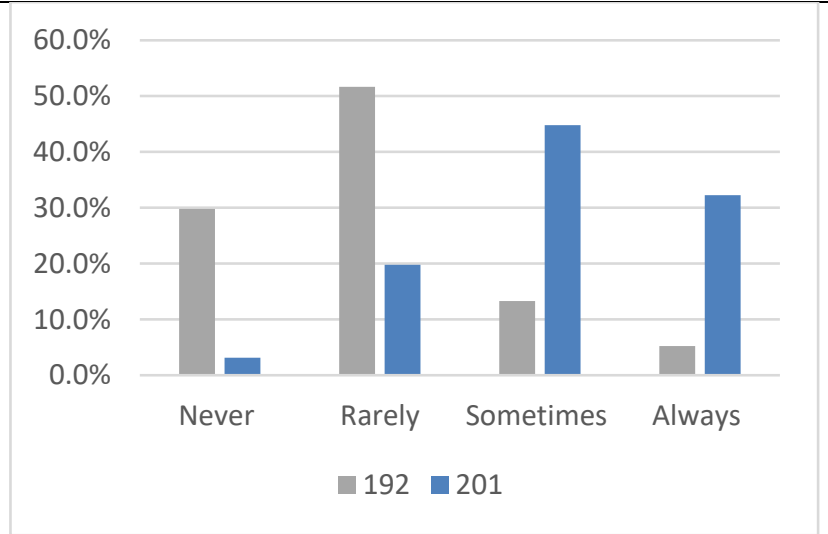




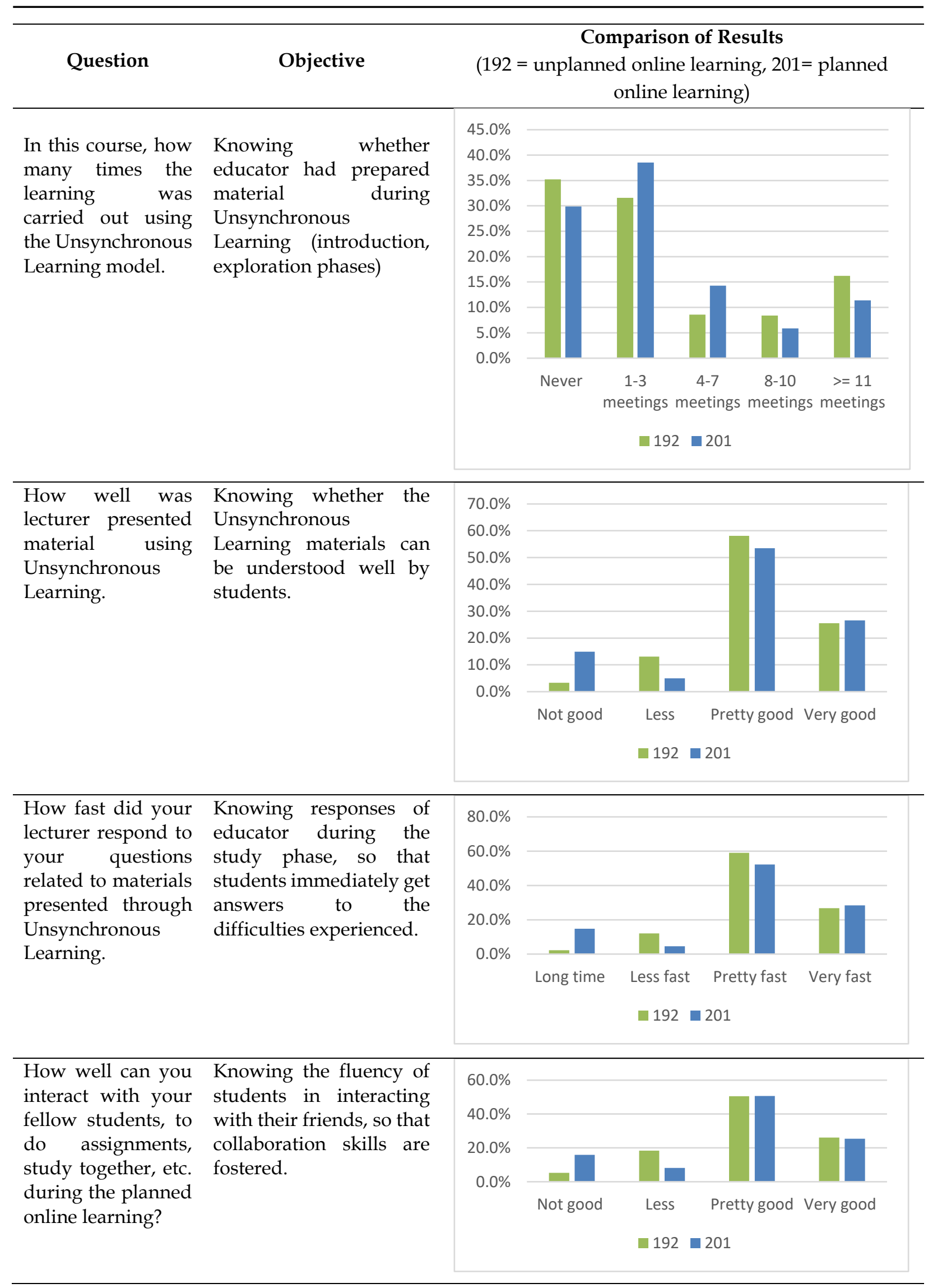




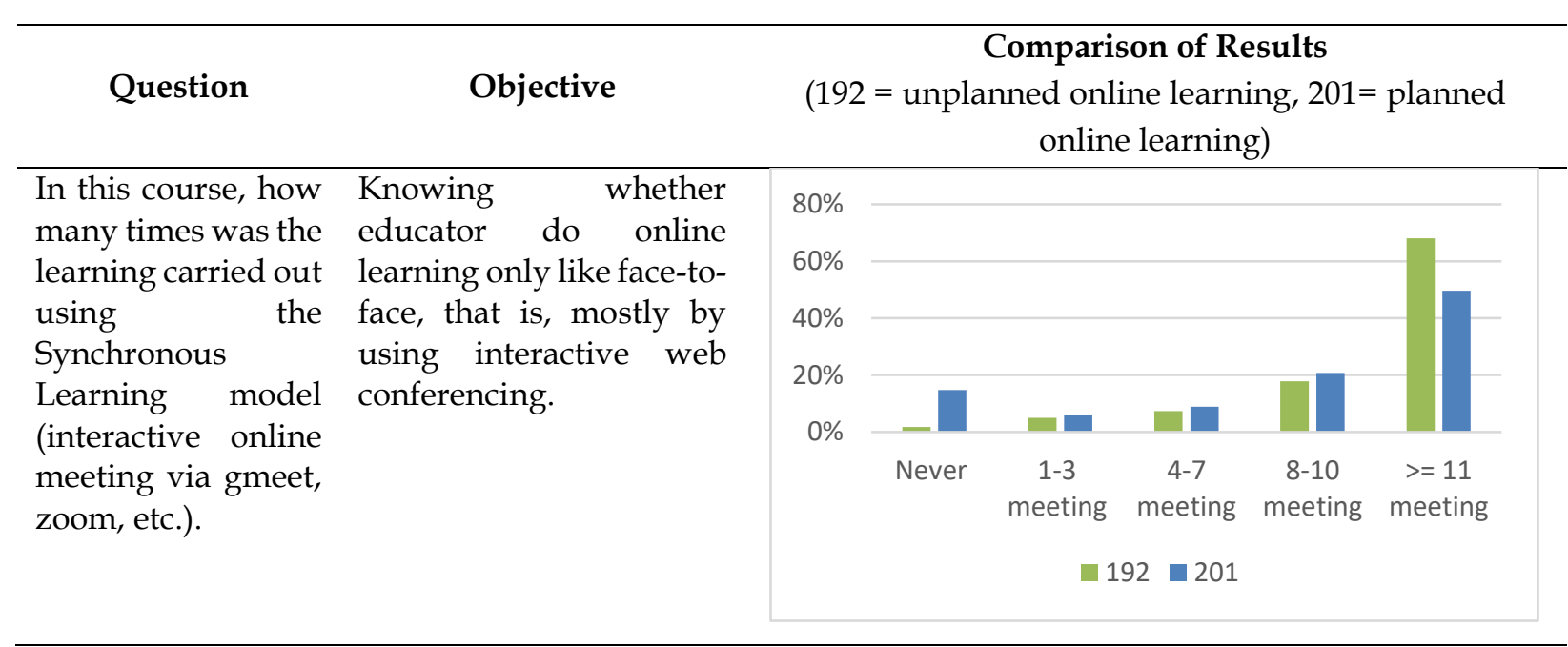

From table 3, it is found that in general, students give a better response than before the treatment of learning.

\section{CONCLUSION}

From the data obtained based on the results of the student response questionnaires, it was found that:

a. In the introduction phase, where students need some teaching materials so that they get to know materials that must be studied, students state that there is an increase in material that can be studied first before meeting the educator. In addition, educators have also started to make new habits with students, namely reading materials before online meeting with educators, so that students always learn materials first (URFA, 2018). This is also supported by the Brillian LMS which can inform the engagement of students.

b. In the exploration phase, where students work on LKPD, the use of unsychronous learning mode has increased from nothing, to about 1-3 times, although it is still not too high, it has approached conformity to the phases in the learning model to be used.

c. In study phase, educators have responded to the doubts or difficulties faced by students, because most of students' responses are "fast enough" and "very fast".

d. In the presentation phase, which is intended for students to present their works, it can be seen that there has been a decrease in virtual face-to-face encounters, so it is hoped that a change in the learning model, from teacher centered learning to student centered learning has occurred(Zheng, Bhagat, Zhen, \& Zhang, 2020).

Student response questionnaires in general have shown better results than those during sudden/unplanned online learning, but for each there are still things that need to be improved again, in order to become qualified online learning, including the quality of learning materials. Learning materials must be made more attractive, so that student response questionnaires will all state that they always study learning materials first before participating in the teaching and learning process (Chaeruman, Bintoro, Hartoto, \& Maudiarti , 2019). Another thing that must be improved is the response of educators in the study phase. This phase is very important to motivate the success of students when understanding material (Chaeruman \& Maudiarti, 2018). If responses from educators are too slow, it will reduce the students' desire to learn independently.

The novelty of this research is based on existing references, created online learning that was seriously planned, and not only moving face-to-face learnimh into virtual one. The limitation of this research is that it has not been correlated between the results of questionnaires and the scores of students' learning outcomes in order to know the learning progress of students. 
Change Unplanned Into Planned Online Learning: An Effort To Follow Health Protocols At An Information Technology College During The Covid-19 Pandemic Period

https://doi.org/10.46627/silet.v2i1.62

\section{ACKNOWLEDGMENT}

Thanks to Universitas Dinamika, Surabaya, Indonesia for allowing this research to take place.

\section{REFERENCES}

Adedoyin, O. B., \& Soykan, E. (2020). Covid-19 pandemic and online learning: the challenges and opportunitiesOlasile Babatunde Adedoyin. Interactive Learning Environments , 1-13.

Al-Fraihat, D., Joy, M., \& Sinclair, J. (2017). Identifying Success Factors for e-Learning in Higher Education:. 12 th International Conference on e-Learning,247-256, Orlando, USA: University of Central Florida.

Alhomod, S., \& Shafi, M. M. (2013). Success Factors Of E-Learning Projects: A Technical Perspective. TOJET: The Turkish Online Journal of Educational Technology, 12(2), 247-253.

Al-Maroof, R. S., A. Salloum, S., Hassanien, A. E., \& Shaalan, K. (2020). Fear from COVID-19 and technology adoption: the impact of Google Meet during Coronavirus pandemic. Interactive Learning Environments, 1-16.

Almarzooq, Z. I., Lopes, M., \& Kochar, A. (2020). Virtual Learning During the COVID-19 Pandemic: A Disruptive Technology in Graduate Medical Education. Journal of the American College of Cardiology, 75(20), 2635-2638.

Alqahtani, A. Y., \& A. Rajkhan, A. (2020). E-Learning Critical Success Factors during the COVID19 Pandemic: A Comprehensive Analysis of E-Learning Managerial Perspectives. Education Sciences, 10(9), 216-231.

Arends, R. I. (2014). Learning to Teach. New York: Mc Graw Hill.

Arkorful, V., \& Abaidoo, N. (2014). The role of e-learning, the advantages and disadvantages of its adoption in Higher Education. International Journal of Education and Research, 2(12), 397410.

Bakia, M., Shear, L., Toyama, Y., \& Lasseter, A. (2012). Understanding the Implications of Online Learning for Educational Productivity. Washington DC: Center for Technology in Learning.

Bergmann, J., \& Sams, A. (2012). Flip Your Classroom: Reach Every Student in Every Class Every Day. Washington DC: Internal Society for Technology in Education.

Bestiantono, D. S., Agustina, P., \& T-H Cheng. (2020). How Students' Perspectives about Online Learning Amid the COVID-19. Studies in Learning and Teaching, 1(3), 133-139.

Chaeruman, U. A., \& Maudiarti, S. (2018). Quadrant of Blended Learning: a Proposed Conceptual Model for Designing Effective Blended Learning. Jurnal Pembelajaran Inovatif, 1(2), 1-5.

Chaeruman, U. A., Bintoro, T., Hartoto, \& Maudiarti , S. (2019). How Do Teachers Perceive Modern Instruction? An Online Survey to Pre-Service and in-Service Teachers. Advances in Social Science, Education and Humanities Research, 372, 242-246.

Chaeruman, U. A., Wibawa , B., \& Syahrial, Z. (2020). Development of an Instructional System Design Model as a Guideline for Lecturers in Creating a Course Using Blended Learning Approach. International Journal of Interactive Mobile Technologies (iJIM), 14(14), 164-181.

Dhull, I., \& MS. Sakshi. (2017). International Education \& Research Journal (IERJ), 3(8), 32-34.

Eggen, P., \& Kauchak, D. (2011). Strategies for Teachers. Teaching Content and Thinking Skills. USA: Allyn and Bacon.

El-Seoud, M. S., Taj-Eddin, I. A., Seddiek, N., M. El-Khouly, M., \& Nosseir, A. (2014). E-Learning and Students' Motivation: A Research Study on the Effect of E-Learning on Higher Education. International Journal of Emerging Technologies in Learning (iJET), 9(4), 20-26.

Fadillah, A., Nopitasari, D., \& P. Pradja, B. (2020). Blended Learning ModelDuring the Covid19Pandemic: Analysis of Student's' Mathematical Disposition. Jurnal Teori dan Aplikasi Matematika, 4(2), 173-181.

Famularsih, S. (2020). Students' Experiences in Using Online Learning Applications Due to COVID-19 in English Classroom. Studies in Learning and Teaching, 1(2), 112-121.

Joyce, B. R. (2014). Models of Teaching. Massachussetts: Allyn and Bacon. 
Change Unplanned Into Planned Online Learning: An Effort To Follow Health Protocols At An Information Technology College During The Covid-19 Pandemic Period

Lemay, D. J., Doleck, T., \& Bazelais, P. (2021). Transition to online teaching during the COVID-19 Pandemic. Interactive Learning Environments, 1-11.

Moodle. (2020, May 2020). Moodle Docs. Retrieved from https://docs.moodle.org/39/en/Main_page

Nassren, N., Abdullah Alawi, G. A., \& Shagufta, N. A. (2014). Analyzing the Components of Online Learning and Their Inter-relatedness. European Academic Research, 2(7), 9682-9705.

Nguyen, T. (2015). The Effectiveness of Online Learning: Beyond No Significant Difference and Future Horizons. MERLOT Journal of Online Learning and Teaching, 11(2), 309-319.

Pappas, C. (2020, September 16). The Best Learning Management Systems (2020 Update). Retrieved from eLearning Industry: https:/ / elearningindustry.com/the-best-learning-managementsystems-top-list

Parsazadeh, N., Mohd Zainuddin, N. M., Ali, R., \& Hematian , A. (2013). A Review On The Succes Factors Of E-Learning. The Second International Conference on e-Technologies and Networks for Development (ICeND2013) (pp. 42-49). Kualalumpur, Malaysia: UTM .

Simamora, R. M. (2020). The Challenges of Online Learning during the COVID-19 Pandemic: An Essay Analysis of Performing Arts Education Students. Studies in Learning and Teaching, 1(2), 86-103.

Simamora, R. M., D de Fretes, \& Purba, E. (2020). Practices, Challenges, and Prospects of Online Learning during COVID-19 Pandemic in Higher Education: Lecturer Perspectives. Studies in Learning and Teaching, 1(3), 185-208.

Sun, A., \& Chen, X. (2016). Online Education and Its Effective Practice: A Research Review. Journal of Information Technology Education: Research, 15, 157-190.

Sunarto, M. D. (2021). The Development of Flipped Learning Model Based on MyBrilian to Support Planned Online Learning. Jurnal Penelitian Dan Pengkajian Ilmu Pendidikan: ESaintika, 5(1), 27-45.

Sunarto, M. D. (2021). The Development of Flipped Learning Model Based on MyBrilian to Support Planned Online Learning. Jurnal Penelitian Dan Pengkajian Ilmu Pendidikan: ESaintika, 5(1).

Sunarto, M. D. (2021). The Readiness of Lecturers in Online Learning During the Covid-19 Pandemic at the Faculty of Information Technology and the Faculty of Economics and Business. IJORER : International Journal of Recent Educational Research, 2(1), 54-64.

Sutomo, E., Sunarto, M., Hariadi, B., Sagirani, T., Nurcahyawati, V., Amelia , T., \& Koentjoro, E. Y. (2020). Panduan Penggunaan Brilian. Surabaya, Indonesia: Universitas Dinamika.

Tang, T., M. Abuhmaid, A., Olaimat, M., M. Oudat, D., Aldhaeebi , M., \& Bamanger, E. (2020). Efficiency of flipped classroom with online-based teaching under COVID-19. Interactive Learning Environments, 1-13.

Tang, T., M. Abuhmaid, A., Olaimat, M., M. Oudat, D., Aldhaeebi, M., \& Bamanger, E. (2020). Efficiency of flipped classroom with online-based teaching under COVID-19. INTERACTIVE LEARNING ENVIRONMENTS, 1-13.

Trianto. (2014). Model Pembelajaran Terpadu; Konsep, Strtegi dan Implementasinya dalam Kurikulum Satuan Tingkat Pendidikan (KTSP). Jakarta: PT Bumi Aksara.

Tuaycharoen, N. (2021). University- Wide Online Learning During Covid-19 : From Policy to Practice. International Journal of Interactive Mobile Technologies (iJIM), 15(2), 38-46.

URFA, M. (2018). Flipped Classroom Model and Practical Suggestions. Journal of Educational Technology \& Online Learning, 1(1), 47-59.

Yildiz, E. P., Tezer, M., \& Uzunboylu, H. (2018). Student Opinion Scale Related to Moodle LMS in an Online Learning Environment:Validity and Reliability Study. International Journal of Interactive Mobile Technologies (iJIM), 12(4), 97-108.

Zheng, L., Bhagat, K. K., Zhen, Y., \& Zhang, X. (2020). The Effectiveness of the F lipped C lassroom on S tudents' L earning Achievement a nd Learning Motivation: A Meta Analysis. Educational Technology E Society, 23(1), 1-15. 
Change Unplanned Into Planned Online Learning: An Effort To Follow Health Protocols At An Information Technology College During The Covid-19 Pandemic Period

https://doi.org/10.46627/silet.v2i1.62

Author (s):

* M.J. Dewiyani Sunarto (Corresponding Author)

Universitas Dinamika

Jl. Raya Kedung Baruk No.98, Kedung Baruk, Rungkut, Surabaya, 60298

Email: dewiyani@dinamika.ac.id 